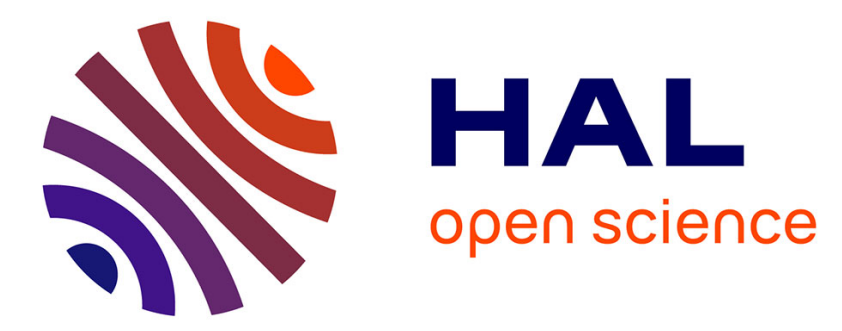

\title{
Effects of plane of nutrition and age at start of nutritional treatment on body growth, onset of puberty, corpora lutea function and fertility in Boran $\mathrm{x}$ Friesian heifers
}

\author{
Azage Tegegne, H Khalili, E Mukasa-Mugerwa, A Lahlou-Kassi
}

\section{To cite this version:}

Azage Tegegne, H Khalili, E Mukasa-Mugerwa, A Lahlou-Kassi. Effects of plane of nutrition and age at start of nutritional treatment on body growth, onset of puberty, corpora lutea function and fertility in Boran x Friesian heifers. Annales de zootechnie, 1995, 44 (Suppl1), pp.325-325. hal-00889482

\section{HAL Id: hal-00889482 https://hal.science/hal-00889482}

Submitted on 1 Jan 1995

HAL is a multi-disciplinary open access archive for the deposit and dissemination of scientific research documents, whether they are published or not. The documents may come from teaching and research institutions in France or abroad, or from public or private research centers.
L'archive ouverte pluridisciplinaire HAL, est destinée au dépôt et à la diffusion de documents scientifiques de niveau recherche, publiés ou non, émanant des établissements d'enseignement et de recherche français ou étrangers, des laboratoires publics ou privés. 


\title{
Effects of plane of nutrition and age at start of nutritional treatment on body growth, onset of puberty, corpora lutea function and fertility in Boran $x$ Friesian heifers
}

\author{
Azage Tegegne 1, H Khalili 2, E Mukasa-Mugerwa 1, A Lahlou-Kassi 1 \\ 1International Livestock Research Institute (ILRI), PO Box 5689, Addis Abeba, Ethiopia; ${ }^{2}$ Agricultural Research
} Centre, Institute of Animal Production, 31600, Jokioinen, Finland

The objective was to determine the effects of plane of nutrition and age at the start of nutritional treatment on body growth, reproductive development and function in Boran x Friesian heifers. Heifers $(n=47)$ were divided into early or late age groups with mean ( \pm SEM) age and body weight $6.7 \pm 0.52$ and $12.4 \pm 0.64$ months and $96.9 \pm 3.4$ and 122.5 $\pm 3.5 \mathrm{~kg}$, respectively. Within age group, heifers were allocated to a high (HPN) or a low (LPN) plane nutrition based on body weight, kept in group pens and provided with grass hay, water and mineral licks ad libitum. Heifers on HPN and LPN were fed concentrate until first conception at a rate of 1.60 and $0.70 \%$ of body weight. Concentrate intake was determined daily. Heifers were continuously observed and teaser bulls assisted in oestrus detection. Ovaries were examined per rectum once a week for cyclic activity and blood samples were collected twice weekly until pregnancy was established for determination of plasma progesterone concentrations. Puberty was determined using combined data from observation, rectal palpation and plasma progesterone concentrations.

Heifers on HPN had higher supplementary diet intake ( $3.3 \pm 0.13 \mathrm{vs} 1.4 \pm 0.13 \mathrm{~kg} / \mathrm{day})$ and faster growth rate (ADG) to puberty $(440 \pm 16.7$ vs $333 \pm 17.1 \mathrm{~g} /$ day $; P<0.001)$ than those on LPN. Age at the start of supplementary feeding did not influence both feed intake and growth rate. Puberty occurred earlier $(P<0.01)$ in heifers on HPN than on LPN. Between 13 and
20 months of age, 46 and $5 \%$ of the heifers on HPN and on LPN attained puberty. Body condition score at puberty was better $(P<0.01)$ in heifers reared on HPN than on LPN. There were no differences between treatment groups in body weight, withers height, heart girth and pelvic area at puberty. Body weight at puberty was correlated with withers height $(0.82)$ and heart girth $(0.90)$ at puberty. Plasma progesterone profiles revealed that nonpuberal oestrus and ovulations without oestrus were observed in 24.6 and $35.4 \%$ of the heifers before the onset of puberty without any influence of plane of nutrition. Pregnancy to first service was higher $(P>0.05)$ in heifers reared on HPN than on LPN ( 40.0 vs $26.5 \%$ ) and in heifers which started nutritional treatment early than late (38.8 vs $27.5 \%$ ). Embryonic mortality occurred in 24 and $39 \%$ of the heifers reared on HPN and LPN $(P<0.01)$ and in 27 and $32 \%$ of the heifers which started nutritional treatment at an early than at late age. Heifers reared on HPN conceived about six months earlier $(\mathrm{P}<0.01)$ than those on LPN, but without any difference in body weight at first conception. Results from this study showed that plane of nutrition during the pre-conception period influences body growth and reproductive development and functions in heifers. Early first calving in heifers could ensure an earlier economic return to smallholder dairy producers in tropical environments. However, the effect of early calving on lactation performance and postpartum reproduction has to be evaluated.

\begin{tabular}{|c|c|c|c|c|c|}
\hline \multirow[b]{2}{*}{ Variables } & \multicolumn{2}{|c|}{ High plane nutrition } & \multicolumn{2}{|c|}{ Low plane nutrition } & \multirow[b]{2}{*}{ SEM } \\
\hline & Early & Late & Early & Late & \\
\hline $\begin{array}{l}\text { ADG, g/d } \\
\text { Pubertal traits }\end{array}$ & $430.1^{a}$ & $449.0^{\mathrm{a}}$ & $334.3^{\mathrm{b}}$ & $332.1^{\circ}$ & 22.61 \\
\hline Age, mo & $24.5^{a}$ & $24.8^{a}$ & $26.7^{a}$ & $30.0^{b}$ & 11.53 \\
\hline Body weight, kg & $278.9^{a}$ & $284.6^{a}$ & $276.9^{a}$ & $284.9^{a}$ & 11.54 \\
\hline $\begin{array}{l}\text { Body condition score, } \\
\text { Conception }\end{array}$ & $5.9^{a}$ & $6.8^{a}$ & $4.7^{\mathrm{b}}$ & $6.1 \mathrm{a}$ & 0.30 \\
\hline Age, mo & $25.6^{a}$ & $28.3^{a}$ & $30.8^{b}$ & $34.6^{\mathrm{b}}$ & 2.01 \\
\hline Body weight, kg & $290.9^{a}$ & $332.0^{a}$ & $304.6^{a}$ & $323.1^{a}$ & 14.32 \\
\hline Pregnancy to 1st $\mathrm{Al}, \%$ & $54.6^{a}$ & $25.0^{\mathrm{b}}$ & $23.1^{b}$ & $30.0^{\mathrm{b}}$ & \\
\hline Embryonic mortality, \% & $15.4^{a}$ & $33.3^{b}$ & $38.5^{b}$ & $40.0^{\mathrm{b}}$ & \\
\hline
\end{tabular}

Within a row, figures followed by different superscripts differ $(P<0.05)$. 